\title{
The phylogenetic relationships of whale-fall vesicomyid clams based on mitochondrial COI DNA sequences
}

\author{
A. R. Baco ${ }^{1,}$, C. R. Smith ${ }^{1}$, A. S. Peek ${ }^{2}$, G. K. Roderick ${ }^{3}$, R. C. Vrijenhoek ${ }^{2}$ \\ ${ }^{1}$ Department of Oceanography, University of Hawaii, 1000 Pope Road, Honolulu, Hawaii 96822, USA \\ ${ }^{2}$ Center for Theoretical and Applied Genetics, Rutgers University, 71 Dudley Road, New Brunswick, New Jersey 08901-4521, USA \\ ${ }^{3}$ Center for Conservation Research and Training, University of Hawaii, 3050 Maile Way, Gilmore 409, Honolulu, \\ Hawaii 96822, USA
}

\begin{abstract}
Whale skeletons on the deep-sea floor provide sulfide-rich habitats that may act as stepping stones for the dispersal of animals dependent on chemoautotrophic production. However, the phylogenetic relationships between the faunas of whale falls, hydrothermal vents and colds seeps are not fully evaluated. To examine vesicomyid phylogenetic relationships, we collected 10 vesicomyid clams from 2 whale falls on the California margin, one at $1240 \mathrm{~m}$ in the Santa Catalina Basin and one at $960 \mathrm{~m}$ on the slope west of San Nicolas Island. We then compared DNA sequences for a portion of the mitochondrial cytochrome coxidase subunit I gene from the whale-skeleton clams to those from other clam populations in this taxonomically difficult family. Seven adult whale-fall vesicomyids clustered with clams identified as Vesicomya gigas, a species also found near hydrothermal vents in Guaymas Basin (Gulf of California) and Middle Valley (Juan de Fuca Ridge). A single small whale-fall individual clustered with clams identified as Calyptogena kilmeri, a species found at cold seeps in Guaymas Basin, Monterey Bay, and along the Oregon Subduction Zone. A single small whale-fall clam clustered with Calyptogena elongata, a species found in anoxic California basins. Finally, a single adult clam was difficult to assign to any previously examined species group and could represent a new species in the 'gigas/kilmeri' cryptic species complex. With the inclusion of these vesicomyids, whale falls are known to share a total of 16 species with the faunas of deep-sea hydrothermal vents and cold seeps.
\end{abstract}

KEY WORDS: Vesicomyid - Whale bones - Deep sea - Phylogeny - Mitochondrial DNA · COI Hydrothermal vent $\cdot$ Cold seep

\section{INTRODUCTION}

In 1987, a faunal community utilizing sulfide-based chemoautotrophy was discovered on a whale skeleton in the Santa Catalina Basin (SCB). This community exhibited similarities to assemblages found at other deep-sea reducing habitats, such as hydrothermal vents and cold seeps (Smith et al. 1989, McLean 1992, Smith 1992, Pettibone 1993, Bennett et al. 1994, Deming et al. 1997). Since the discovery of the SCB skeleton, additional whale-skeleton communities have been

\footnotetext{
•E-mail:abaco@iniki.soest.hawaii.edu
}

observed in situ, including 1 on the Torishima Seamount (Fujioka et al. 1993, Wada et al. 1994, Naganuma et al. 1996), 2 in Monterey Bay (J. Barry pers. comm.), and 8 on the California Slope west of San Nicolas Island (C. Smith unpubl. data). Whale bones with attached fauna have been trawled up from several other deep-sea sites including 4 skulls from the California Slope (McLean 1992, W. Wakefield pers. comm., A. Baco \& C. Smith unpubl. data), numerous skulls and bones from the Chatham Rise off New Zealand (Gibbs 1987, Marshall 1987, 1994, B. Marshall pers. comm.), and a skull from the deep-sea near Iceland (Waren 1989). Fossil chemoautotrophic communities have also been found associated with 8 fossil 
whale skeletons that are up to 30 million yr old (Goedert et al. 1995). Before the existence of whales, it is possible that large marine reptiles supported similar chemoautotrophy-based communities (Martill et al 1991, Hogler 1994, Marshall 1994).

Sunken whale carcasses may play several roles in the deep sea. First, they may provide habitats for an endemic fauna. For example, the sipunculan Phascolosoma saprophagicum, the Iimpet Pyropelta wakefieldi. and the polychaete Harmothoe craigsmithi have been found only in association with deep-sea whale skeletons (Gibbs 1987, McLean 1992, Pettibone 1993). In addition, whale falls may serve as refugia for organisms dependent on sulfide-based chemoautotrophy, acting as dispersal stepping stones on the generally organic-and sulfide-poor deep-sea floor (Smith et al. 1989). Both roles may be important in maintaining deep-sea biodiversity (Butman et al. 1995).

A stepping-stone role for the whale falls is supported by faunal overlap among whale carcasses and other deep-sea reducing habitats. At least 12 of the animal species living on whale falls have also been reported at hydrothermal vents, cold seeps, and/or anoxic basins (Smith et al. 1989, McLean 1992, Smith 1992, Pettibone 1993, Bennett et al. 1994, Baco et al. 1996, Deming et al. 1997). In addition, 2 species of vesicomyid clams from a whale carcass (Calyptogena pacifica and Vesicomya gigas) are thought to occur at vents and seeps (Smith et al. 1989). However, this conclusion should be treated with caution as subsequent studies of vesicomyids revealed that species identifications based on morphological criteria (i.e. 'morphospecies') can be problematic. Discoveries of genetically distinct, yet morphologically indistinguishable, 'cryptic' species, and the existence of extensive morphological plasticity within genetically well-defined species have raised doubts about prior identifications of many vesicomyid 'species' (Vrijenhoek et al. 1994, Kojima et al. 1995).

Vesicomyids appear to be restricted to deep-sea reducing habitats, including hydrothermal vents (Southward 1985, reviewed in Tunnicliffe 1991), cold seeps (reviewed in Sibuet \& Olu. 1998), and anoxic sediments (Felbeck et al. 1983, Vetter 1985, Distel et al. 1988). Members of this family studied to date depend entirely on sulfur-oxidizing chemoautotrophic endosymbionts for their nutriment (Cavanaugh 1983, Felbeck et al. 1983, Childress et al. 1987, Fiala-Medioni \& LePennec 1988, Fisher 1990). Despite the fragmented distribution of these sulfide-rich habitats, some vesicomyids (e.g. the vent clam Calyptogena magnifica) show essentially no genetic differentiation across vast distances $\left(21^{\circ} \mathrm{N}\right.$ to $18^{\circ} \mathrm{S}$ on the East Pacific Rise), indicating effective long-distance dispersal (Karl et al. 1996). The large, yolk-filled eggs of C. magnifica are buoyant at ambient temperatures and pressures, and they transmit the obligatory sulfur-oxidizing endosymbionts to zygotes (Berg 1985, Endow \& Ohta 1990, Cary \& Giovannoni 1993). Successful establishment of a vesicomyid population depends on a suitable source of reduced sulfur compounds.

We recently collected new vesicomyid specimens from 2 whale-fall sites on the California margin to determine whether whale falls contained clams that also occur at hydrothermal vents and cold seeps. We compared the DNA sequences of a 710 base pair (bp) region of the mitochondrial cytochrome c oxidase subunit I gene (COI) from the whale-fall clams to previously published vesicomyid sequences (Peek et al. 1997). Our analysis indicates that the whale-fall clams represent at least 3 vesicomyid species that occur at other reducing habitats in the northeast Pacific, supporting the hypothesis that whale-falls provide alternative habitats for a variety of sulfophilic deep-sea species.

\section{METHODS}

Study site and collection of specimens. We collected live clams from 2 whale-skeleton sites on the California margin (Fig. 1, Table 1). The first skeleton lies on the floor of the SCB $\left(33^{\circ} 12^{\prime} \mathrm{N}, 118^{\circ} 30^{\prime} \mathrm{W}\right)$ at a water depth of $1240 \mathrm{~m}$. Characteristics of the SCB and the whale community are summarized in Bennett et al (1994), and Smith et al. $(1989,1998)$. Three adult clams were collected from this site with the submersible ALVIN (November 1991), and 6 were collected with the remotely operated vehicle ATV and the submersible TURTLE (May 1995). Collections were made with a scoop net from sediments surrounding the whale bones. On shipboard, clams were immediately placed on ice and dissected to remove gill and adductormuscle tissues. Gill and adductor tissues were frozen on dry ice, and transported on dry ice to Rutgers University where they were stored at $-80^{\circ} \mathrm{C}$. Adductor muscle tissues were minced and DNA was extracted by a standard CTAB protocol (Doyle \& Dickinson 1987).

The second skeleton lies on the slope $37 \mathrm{~km}$ west of San Nicolas Island ( $\mathrm{SNI}^{\circ} 33^{\circ} 20.3477^{\prime} \mathrm{N}, 119^{\circ} 58.8414^{\prime} \mathrm{W}$ ) at a water depth of $960 \mathrm{~m}$. The SNI whale-fall community was similar to that in SCB with the exception that adult vesicomyids were not abundant (Baco et al. 1996). The single small vesicomyid collected at the SNI site in May 1995 was found attached to a whale vertebra recovered by the ATV The entire specimen was preserved in $95 \%$ non-denatured ethanol. Subsequently, soft tissues were removed from the shell, symbiont-containing gills were removed, and all remaining tissues were used for DNA extraction, as above 


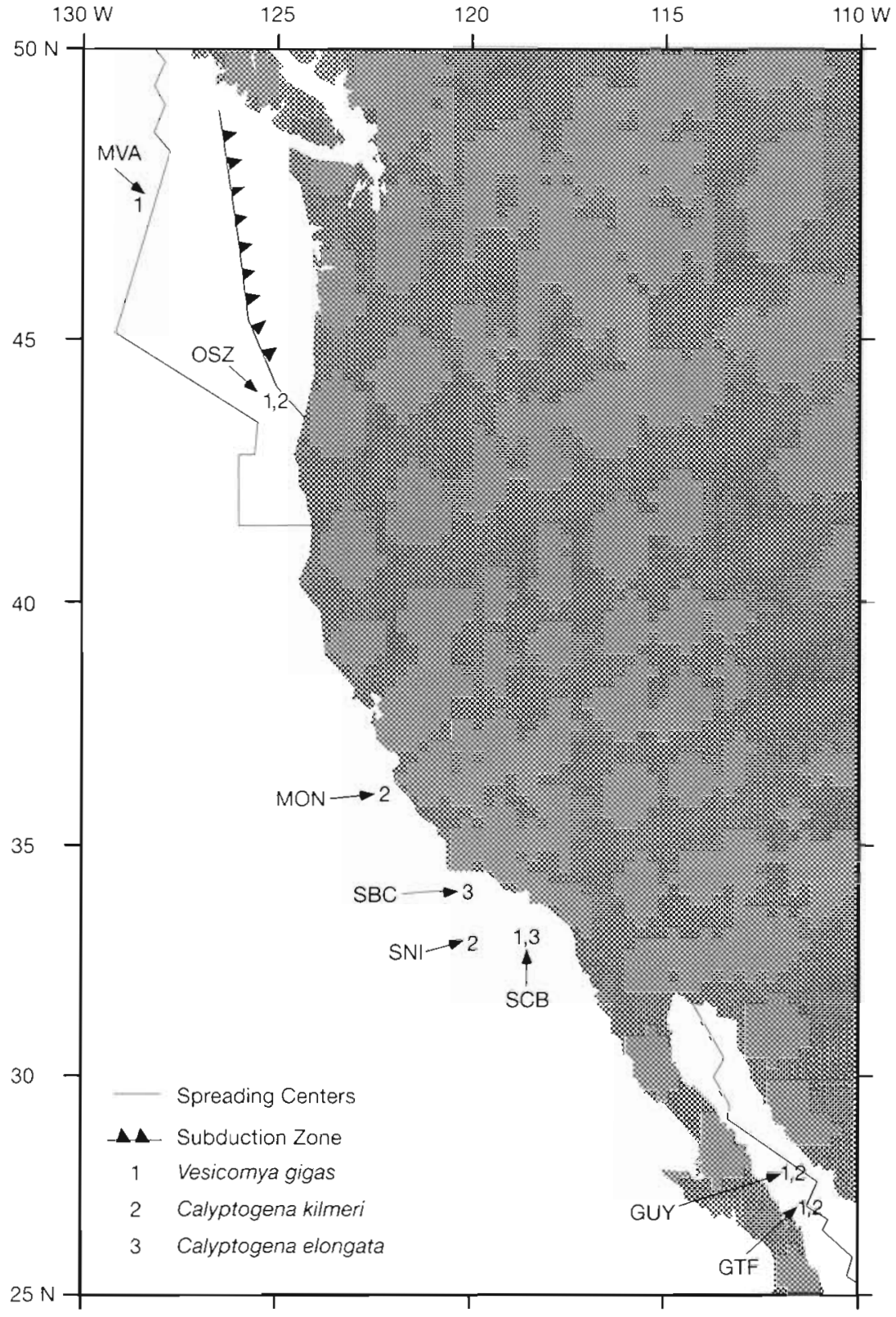

Fig. 1. Locations of reducing habitats in the northeast Pacific relevant to this study. Location abbreviations: MVA = Middle Valley vents, OSZ = Oregon Subduction Zone seeps, $\mathrm{MON}=$ Monterey seeps, $\mathrm{SBC}=$ Santa Barbara channel anoxic basin, SNI = San Nicolas Island whale, SCB = Santa Catalina Basin whale, GUY = Guaymas Basin vents, GTF = Guaymas Transform Fault seeps

file was $1 \mathrm{~min}$ at $94^{\circ} \mathrm{C}, 1 \mathrm{~min}$ at $40^{\circ} \mathrm{C}$, $1 \mathrm{~min}$ at $72^{\circ} \mathrm{C}$ for 30 cycles with a $10 \mathrm{~min}$ extension at $72^{\circ} \mathrm{C}$. Amplification products were purified using Qiagen purification (Qiagen, Chatsworth, CA). Cycle sequencing reactions were dye-terminated dideoxy labeling reactions (ABI, Foster City, CA) following manufacturer's protocols, using vesicomyid primers VesLCO and VesHCO (see Peek et al. 1997 for primer sequences), followed by running on an ABI373 automated sequencer (ABI, Foster City, CA). Sequences were edited and aligned using 'Auto Assembler' and 'Sequence Navigator' (ABI, Foster City, CA) and GDE programs (Smith et al. 1994). The number of nucleotide transitions and transversions was estimated with MEGA (Kumar et al. 1993). The 10 new vesicomyid sequences are deposited in GenBank with accession numbers AF1 14391-392 to AF141296-303.

Whale-fall clam sequences were aligned with COI sequences of vesicomyids from hydrothermal vents, cold seeps, and anoxic basins (data from Peek et al. 1997. Table 1). As in the study by Peek et al. (1997), we used maximum likelihood (fastDNAml 1.0.6; Olsen et al. 1994 ) and parsimony methods (PAUP 3.1.1; Swofford 1993) for phylogenetic analyses. The veneroid clam Mercenaria mercenaria was used as an outgroup. Alternate phylogenetic hypotheses were constructed with MacClade 3.06 (Maddison \& Maddison 1992) and tested for likelihood by the Kishino-Hasegawa method in DNAml (Kishino \& Hasegawa 1989).

\section{RESULTS}

Unambiguous sequences were obtained for $a>700 \mathrm{bp}$ region of the mitochondrial COI gene in 10 whale-fall

Genetic analyses. Using the polymerase chain reaction (PCR see Saiki et al. 1988), and the HCO2198 and LCO1492 primers of Folmer et al. (1994), we amplified a 710 bp region of the mitochondrial COI gene from the 10 new specimens. The $25 \mu \mathrm{L}$ PCR reaction mixtures contained: $1 \times$ Taq DNA Polymerase buffer (Promega, Madison, WI), $2.5 \mathrm{mM} \mathrm{MgCl} 2,200 \mu \mathrm{M}$ dNTP's, $1 \mathrm{mM}$ of each primer, 5 to $50 \mathrm{ng}$ of template DNA, and $0.5 \mathrm{U}$ Taq DNA Polymerase (Promega). The amplification reaction pro- vesicomyids. We considered these new sequences in the context of the 516 bp region of the 52 vesicomyid sequences published by Peek et al. (1997). Altogether, the observed number of transitions (Ts) and transversions (Tv) for the 62 sequences increased linearly with genetic distance, providing no evidence for saturation within the vesicomyids. Consequently, all substitutions were used in the subsequent phylogenetic analyses. Because the Ts:Tv ratio was approximately $2: 1$ aver- 


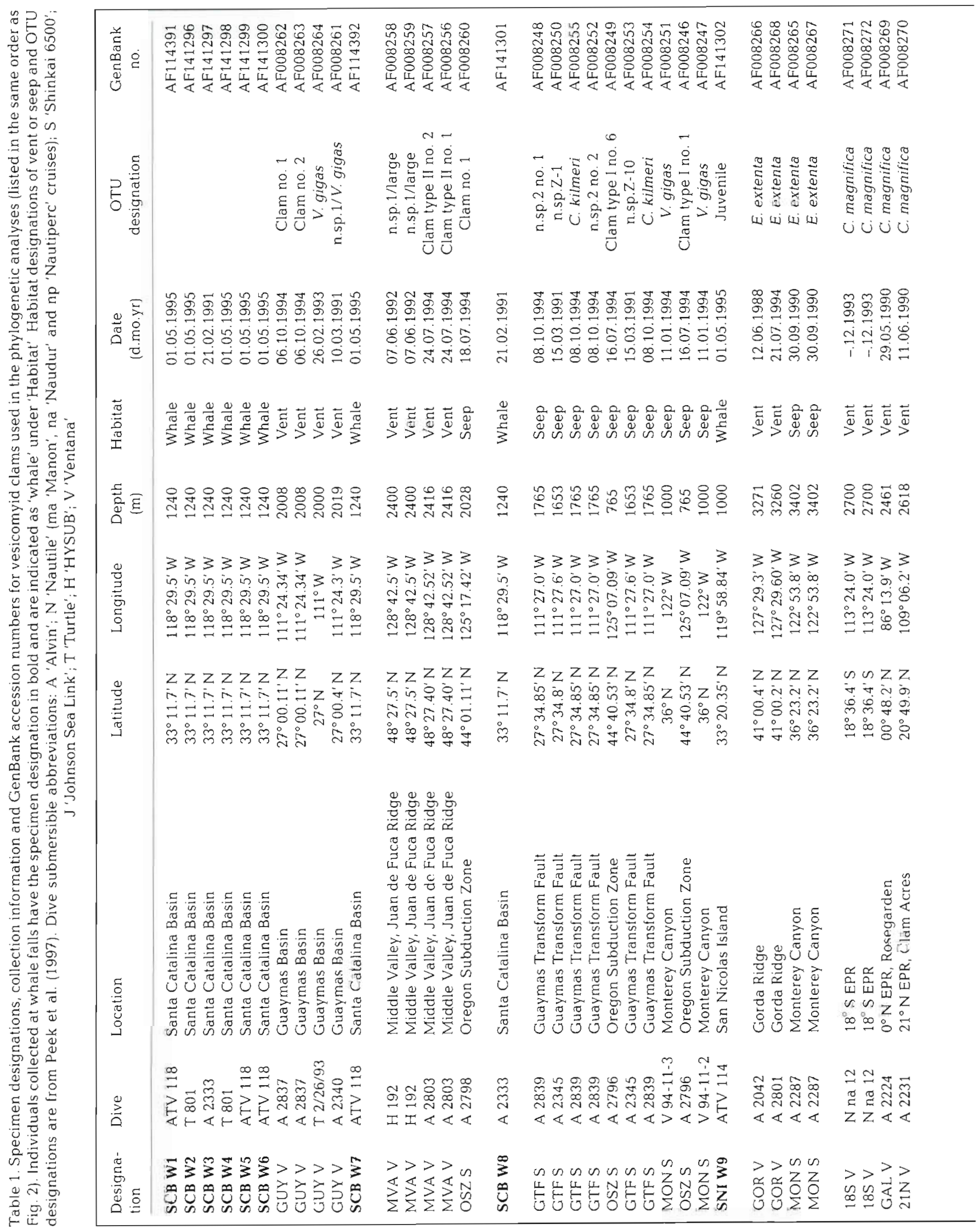




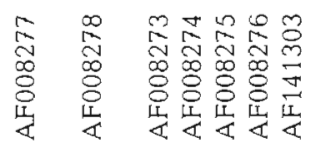

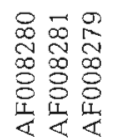

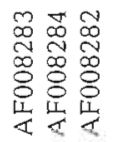

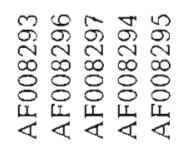

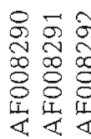

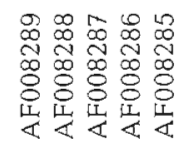

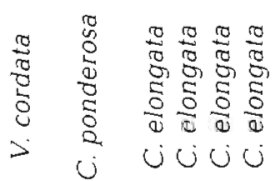

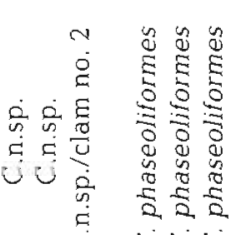

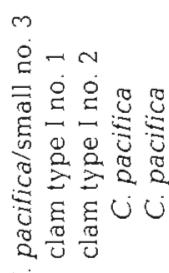

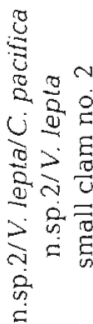

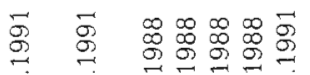

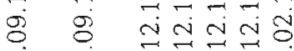

Е

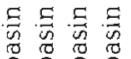

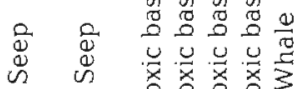

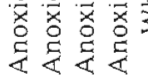

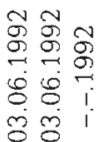

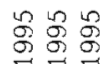

今ं

$\sigma g$

宁

क जि 50

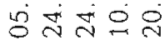

응 응 용

品离

$\begin{array}{ll}a & 0 \\ 0 & 0 \\ 0 & 0 \\ & 0\end{array}$

$\overrightarrow{0} \vec{D} \vec{D} \overrightarrow{0}$
$>>D$
$>$

옹용

80

$\Leftrightarrow \leq 1$

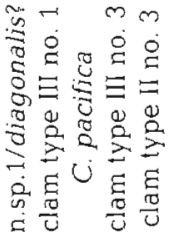

임 8888

in in 3333 in

ㄱ 0 잉ㅇㅇㅇㅇㅇ

강

z $z$

iv के

च च

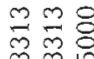

333

60

过 in

这

$z Z z$

$\infty$ is

¿10

少
山山山

응응으

켬

过 桨 范

zZz 888

$8 \%$ 원요욤

乙元乙乙一

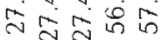

品品品

Z Z

กั่

8 in

令怘 in

$\pi \%$

용

둥졍

둥요

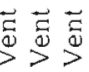

웅응응응

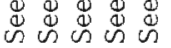

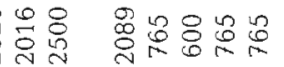

33

3333

च항 3 형

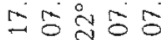

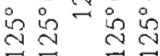

Z奴

的的的管

유ㅇㅝㅠ 앙웡
告

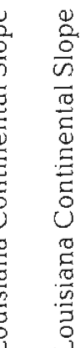
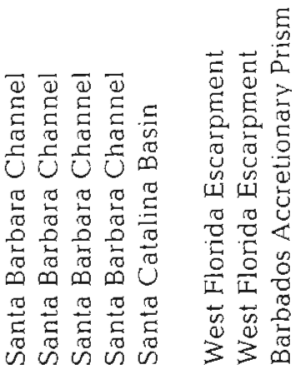
웅워융

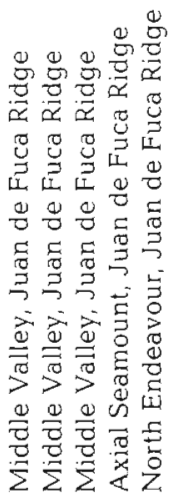

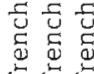

点皇

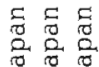

ज ल

ฟैํํำ

$\varangle \ll Z$

$\underset{\sim}{N} \underset{\sim}{N}$

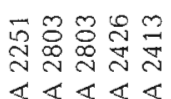

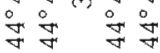
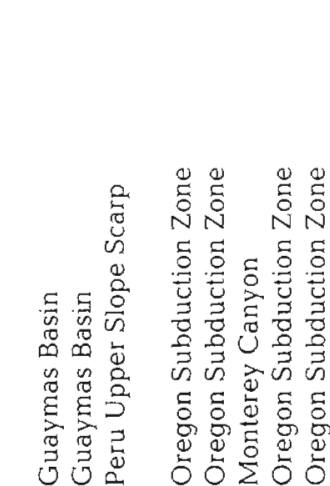

a n suses

ก in es

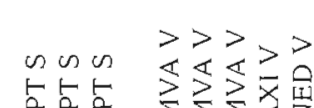

ॠָ心

$\alpha$
$\varangle<2$

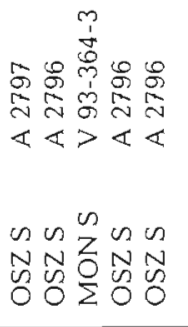

aged across all codon positions, we used a Kimura 2-Parameter estimate in further analyses.

The present phylogenetic analysis of the combined 62 vesicomyid sequences and outgroup produced essentially the same tree topology reported by Peek et al. (1997) (Fig. 2). The present whale-fall clams appear to represent at least 3 discrete species. A single clam, W10 from the SCB whale site, clustered with specimens of Calyptogena elongata from the Santa Barbara Channel. The other $9 \mathrm{SCB}$ individuals clustered within the 'gigas/kilmeri' cryptic species complex. A single small specimen, W9, from the SNI site clustered with vesicomyids from seeps along the Guaymas Basin Transform Fault, the Oregon Subduction Zone, and Monterey Bay (Group A, Fig. 2), which are thought to represent Calyptogena kilmeri (J. Barry pers. comm.). Seven large individuals, W1 to W7, from the SCB site were essentially identical to clams from the Guaymas Basin hydrothermal vents, and related to similar clams from Middle Valley on the Juan de Fuca Ridge and from seeps on the Oregon Subduction Zone. Taken together, this diverse monophyletic group of clams (Group B, Fig. 2) is currently thought to represent the species Vesicomya gigas (J. Barry pers. comm.).

It proved more difficult to assign the SCB clam specimen W8 to an existing taxon. The present maximum likelihood analysis placed it basal to the Group B clade; however, the bootstrap support for this arrangement was weak (Fig. 2). We tested the likelihood of 4 different tree topologies regarding the placement of W8 under the 'user trees' option of DNAml (Felsenstein 1981). The tests showed that placement of W8 within the Group B clade $\log _{\mathrm{e}}$ likelihood (lnLi-4127.44, SD 12.26) was not significantly different from the maximum likelihood topology $(\operatorname{lnLi}-4106.77)(p=0.093)$. However, placement of W8 within the Group $A$ clade (lnLi -4171.92, SD 14.47) or 


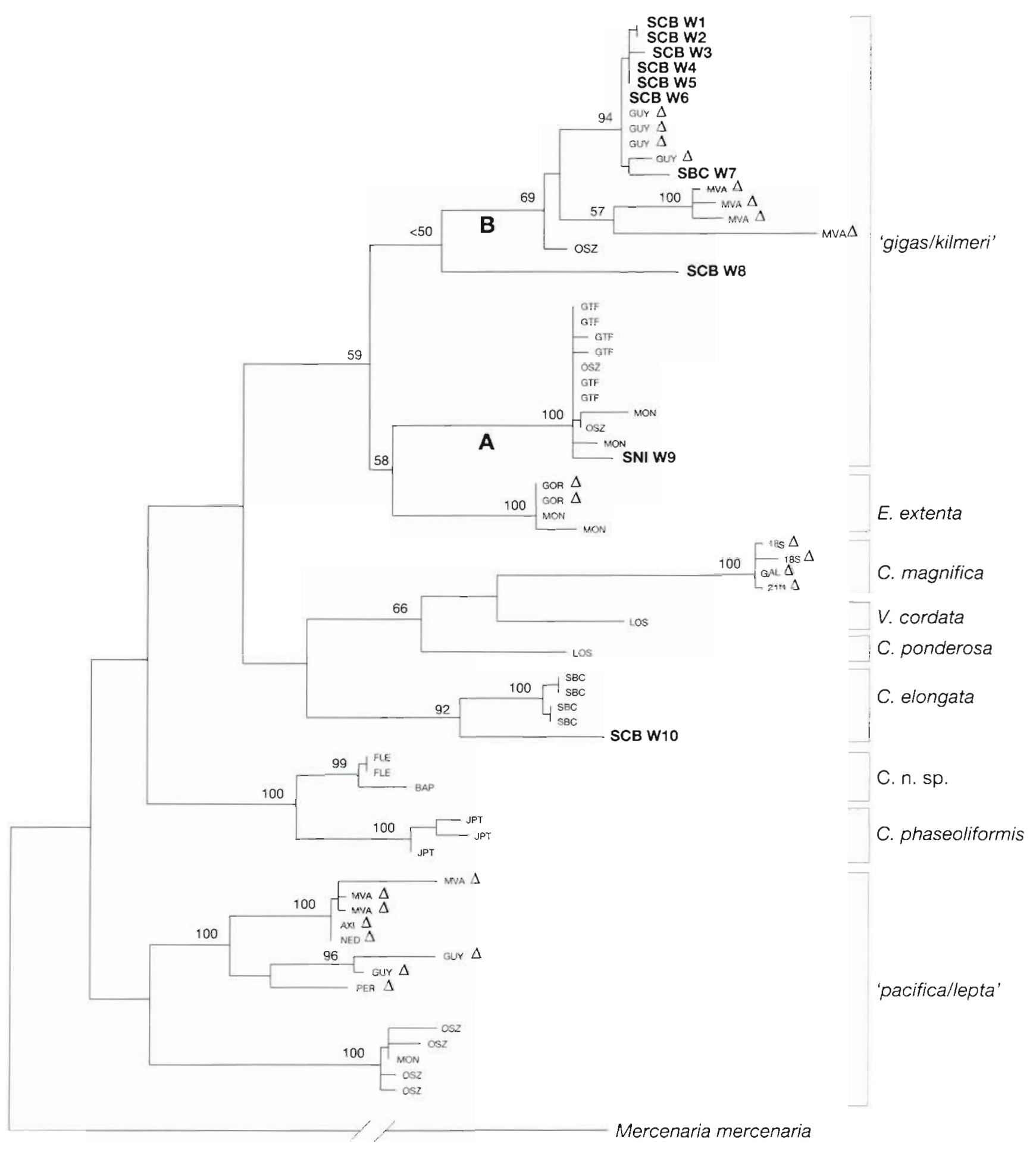

0.1

Fig. 2. Maximum likelihood phylogeny of vesicomyids based on a 516 base pair region of the mitochondrial cytochrome $c$ oxidase subunit I gene, $\log _{e} L$ ikelihood (InLi) of -4106.77 . Bootstrap values (numbers at nodes) are expressed as the percent of 100 replications (values less than 50 not shown). The 10 whale-fall sequences (W1 to W10) and the location abbreviations SCB (Santa Catalina Basin) and SNI (San Nicolas Island slope) are in bold type. The remaining sequences retain the OTU designations of Peek et al. (1997). $\Delta$ : specimens collected from hydrothermal vent sites. GenBank accession numbers and collection information for specimens are listed in Table 1 in the order they appear in the figure 
within the Ectenagena extenta clade $(\operatorname{lnLi}-4172.65$, SD 13.62) were both significantly worse $(p<0.00001)$ than the maximum likelihood topology. Thus, it remains unclear whether W8 represents a highly divergent form of Vesicomya gigas or a new species in this cryptic species complex.

The distribution of Kimura 2-parameter distances between all pairs of these 62 specimens revealed a bimodal distribution that helped to infer current species assignments (Fig. 3). Intra- and interspecific distances found among specimens of the well-defined species (i.e. not including members from the 'gigas/ kilmeri' and 'pacifica/lepta' cryptic species complexes) could be used to assess the relationships of new specimens. Intraspecific distances were all less than 0.0177, contributing to the notable lower peak of the present bimodal distribution. All interspecific distances for the well-defined species were 0.054 or greater, yielding the second higher peak. The genetic distances between SCB clams W1 to 7 and other group B specimens (putatively Vesicomya gigas) were less than 0.0177 and consistent with conspecificity. Similarly, genetic distances between SNI W9 and other Group A specimens (putatively Calyptogena kilmeri) were all less than 0.0177 and consistent with conspecificity.

Species assignments of the remaining 2 specimens were less clear, however. The SCB W10 specimen was closest to specimens identified as Calyptogena elongata (genetic distances $\leq 0.054$ ) and more divergent from all other taxa (distance $\geq 0.080$ ). Maximum likelihood bootstrapping strongly supported its clustering with C. elongata and we have tentatively considered it a highly divergent variant of this species. Similarly, the SCB W8 specimen was highly divergent from all other taxa. Its closest relationship was with Group B speci-

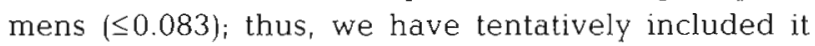
within a diverse complex that probably contains additional cryptic species. Clearly, more specimens of these 2 taxa must be examined with additional genetic markers before confident species assignments can be made.

\section{DISCUSSION}

The present analysis identified at least 3 distinct species of vesicomyid clams sampled from whale falls along the California margin, increasing the number of invertebrate species shared between whale falls and vents or seeps to 16 . Of the 10 whale-fall vesicomyid specimens examined here, 7 clustered within the Group B clade (putatively, Vesicomya gigas), 1 clustered within the Group A clade (putatively, Calyptogena kilmeri), 1 was closely related to $C$. elongata, and the final specimen clustered within the 'gigas/kilmeri' cryptic species complex, and may represent a novel species.

Problems remain with the present species assignments, however. Sequence divergence $(d)$ between the single SCB W10 specimen and individuals of Calyptogena elongata from the Santa Barbara Channel $(d=0.058)$ was greater than that typically found within well-defined species of vesicomyids. In general,
Fig. 3. Distribution of pairwise genetic distances (Kimura 2-parameter) between the 62 vesicomyid sequences. The positions of comparisons involving the present whale-fall specimens are indicated on the distribution. The values on the $x$-axis are the upper end of the binned range, i.e. values $\geq 0$ and $<0.01$ are included in '0.01'

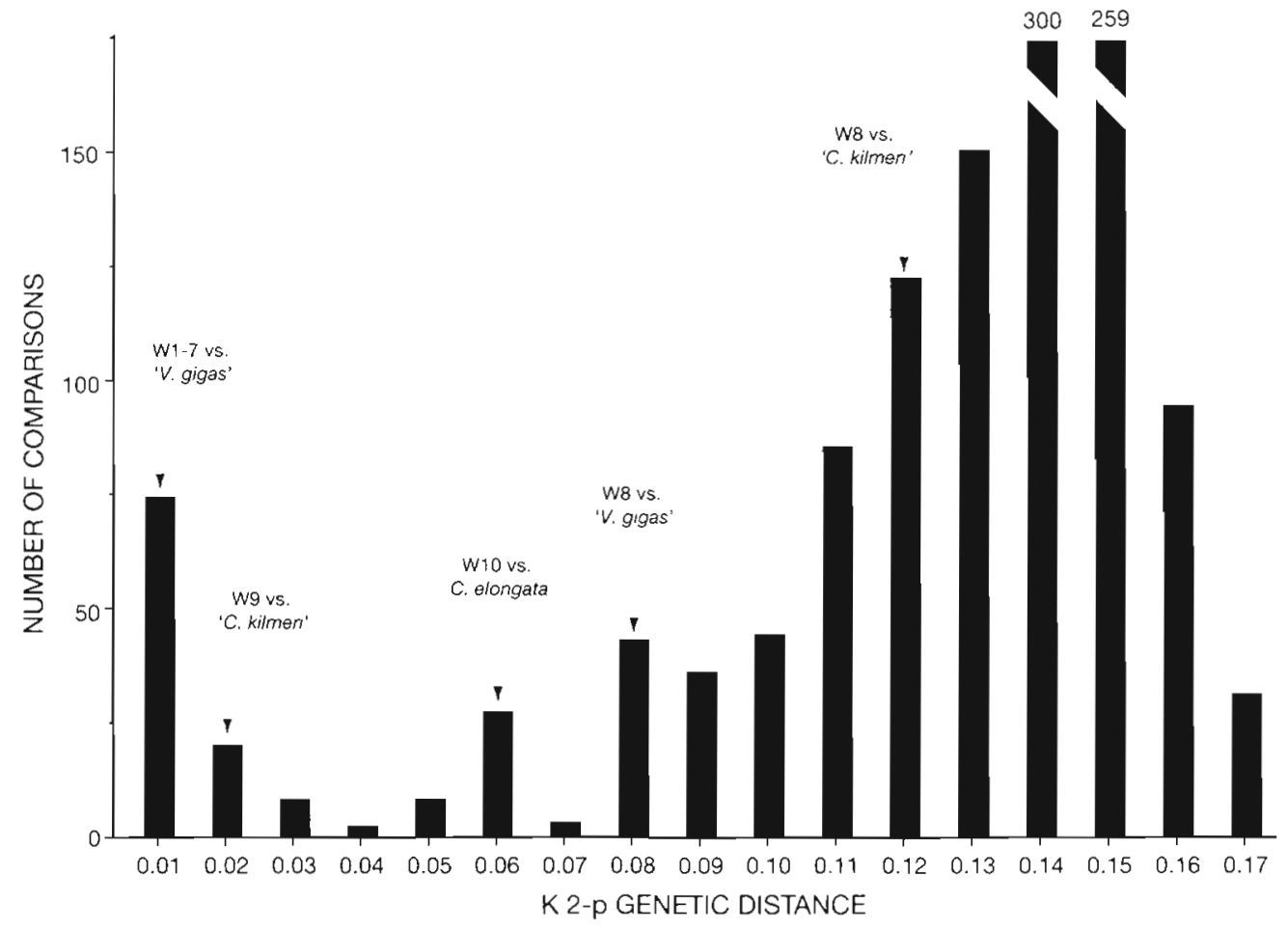


intraspecific divergence for mitochondrial COI was less than 0.018 and interspecific divergence exceeded 0.054. Similarly, divergence between SCB W8 and other members of the 'gigas/kilmeri' cryptic species complex was 0.08 . High $d$ levels notwithstanding, we cannot be confident that these specimens represent novel taxa. Cases are known in bivalve mollusks and other invertebrates where intraspecific divergence of mitochondrial sequences can be high. For example, divergent mitochondrial haplotypes found in Mytilus edulis populations exhibit $d$ values of 0.10 for the same COI region as examined in this study (Hoeh et al. 1996). However, these mitochondrial haplotypes exhibit sexually biased inheritance in $M$. edulis, which has not been examined in vesicomyids. Although we cannot exclude the hypothesis that divergent mitochondrial haplotypes are similarly maintained in vesicomyid species, we found no evidence for heteroplasmy ( 2 or more mitochondrial haplotypes in a single individual), one indicator of sexually biased mitochondrial transmission. In other invertebrates, intraspecific mitochondrial COI $d$ values are generally about 0.01 to 0.02 (reviewed in Avise et al. 1987, Juan et al. 1996). In some beetles however, $d$ values for intraspecific divergence between populations with disjunct geographic locations may be as high as 0.07 to 0.10 (Juan et al. 1996). Perhaps vesicomyid populations follow a pattern similar to beetles.

Clearly, more individuals of the ambiguous vesicomyid taxa must be sampled from a broader geographical range to assess the extent of mitochondrial polymorphism within species. Furthermore, examination of independent nuclear gene loci (e.g. allozymes) could help to resolve relationships among these poorly resolved groups of clams. Better morphological criteria for species assignments may be helpful, but the present criteria based mostly on conchology have been problematic (Boss \& Turner 1980). Future sampling should focus on specimens representative of the size and developmental variation seen in these clams. Larger sample sizes (e.g. $>30$ individuals site $^{-1}$ ) can help address other questions, including the rates of gene flow and modes of dispersal between populations at whale falls and other reducing habitats.
Despite the present taxonomic ambiguities, whale falls clearly provide additional habitat for several vesicomyid species. However, we do not know whether whale falls are ecological sinks that support nonreproductive individuals produced at other sites, or if they contribute significantly to the vesicomyid reproduction and dispersal in the deep-sea. Bennett et al. (1994) estimated a population size of 400 to 800 large vesicomyids at the $\mathrm{SCB}$ skeleton. If these clams primarily represent a single species (putatively Vesicomya gigas in the current study) this skeleton may support a population size as great as has been seen near Guaymas Basin or Middle Valley hydrothermal vents ( $R$. Vrijenhoek pers, obs.). Comparative studies of reproductive condition in whale-fall clams and their vent and seep counterparts are warranted to assess potential contributions to the vesicomyid larval population.

A. Whale-Fall Habitat Conditions Intermediate
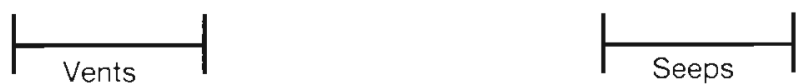

$\mid$\begin{tabular}{|l|} 
\\
Whale Falls
\end{tabular}

Vent Clam Tolerance Range

Seep Clam Tolerance Range

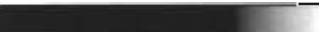

Habitat Gradient

B. Whale-Fall Habitat Conditions Broad and Overlapping
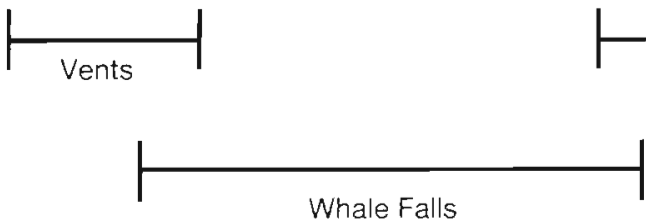

Vent Clam Tolerance Range

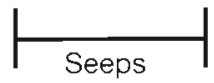

Seep Clam Tolerance Range
Habitat Gradient

Fig. 4. Two models for the habitat distributions of vesicomyid clams. In the first case (A) whale-fall habitat conditions are intermediate to those at hydrotherma! vents and cold seeps for environmental factors necessary for vesicomyid survival. In this case, vesicomyids with broad tolerance ranges are able to colonize either both whales and vents, or both whales and seeps. (B) The whale-fall habitat conditions are broad and overlap those of both vents and seeps. In this case, vent and seep vesicomyids with narrow tolerances are able to colonize whales falls 
Peek et al. (1997) suggested that most vesicomyid lineages are restricted to a single type of reducing habitat (i.e. vents, seeps, or anoxic basins). However, whale fall assemblages deviate from this pattern, containing vesicomyid lineages also found at softsediment hydrothermal vents, cold seeps, and anoxic basins. This suggests that whale falls may offer habitat conditions that are intermediate to, or broader than, those found in other reducing habitats (Fig. 4). If we assume that vents, whales and seeps fall along a gradient of environmental factors required for vesicomyid survival, then there are 2 possible explanations for the habitat distribution of vesicomyid clams (Fig. 4). In the first case, (Fig. 4A), vents, whales and seeps have narrow non-overlapping habitat conditions. In this instance, the vesicomyid species found on whales would need relatively broad tolerance ranges, allowing these species to colonize both whales and vents, or whales and seeps. Alternatively, whale habitats may provide a broad range of the habitat gradient (Fig. 4B), overlapping with the divergent conditions at both vents and seeps. In this case, vesicomyids with narrow tolerance ranges in the regions of overlap could colonize whale falls from vents and seeps. In either case, Fig. $4 \mathrm{~A}$ or $\mathrm{B}$, whale falls appear to represent an intermediate habitat type between soft-sediment vents and seeps, with the potential to provide evolutionary stepping stones between divergent soft-sediment reducing habitats at the deep-sea floor.

Fig. $4 \mathrm{~B}$ is consistent with the findings of Barry et al. (1997) that 2 vesicomyid seep species have narrow sulfide tolerance ranges. Whale falls may offer a broader range of habitat conditions than many other reducing habitats because they offer both hard and soft substrates (e.g. bones and sediments) that are rich in sulfides. However, while sulfide levels at the SCB whale fall in 1988 and 1991 ( $\leq 20 \mu M_{\text {; }}$ Smith et al. 1998) were similar to those measured in the Santa Barbara Channel sediments $(<10 \mu \mathrm{M})$, they were relatively low compared to levels measured at hydrothermal vents ( 6 to $95 \mu \mathrm{M}$ ) and cold seeps (up to $180 \mu \mathrm{M}$ ) (reviewed by Scott \& Fisher 1995). This suggests that the clam species found at whale falls may be restricted to the periphery of more sulfide-rich habitats such as vents and seeps. Furthermore, whale fall species may prefer to burrow, since all the whale fall adult clams were collected from sediments. In fact, all the sites that share vesicomyid species with whale-falls (the Guaymas Basin vents and transform fault seeps, Santa Barbara Channel anoxic basin, Monterey Canyon seeps, Oregon Subduction Zone seeps, and Middle Valley vents) contain soft sediments

The fossil record for the vesicomyids extends to the early Cretaceous, 106 million yr ago (Kanie \& Sakai 1997), but based on a very rough protein molecular clock, Peek et al. (1997) suggested that extant vesicomyids diversified during the Cenozoic Era, less than 50 million yr ago. Inclusion of the present whale-fall specimens does not alter this estimate. The earliest recognized ancestors of modern cetaceans evolved in the Paleocene (about 55 to 65 million $y \mathrm{r}$ ago) and rapidly diversified during the Eocene ( 37 to 55 million yr agol (Gaskin 1982). The first large representatives of cetaceans were the basilosaurids (21 $\mathrm{m}$ in length), which evolved in the Late Eocene about 40 million yr ago (Gaskin 1982, Briggs \& Crowther 1990). Fossil evidence suggests that chemoautotrophic communities including vesicomyid clams have been associated with whale skeletons for at least 30 million yr (Goedert et al. 1995). We note that, based on very rough estimates, the diversification of vesicomyid clams may have been synchronous with the diversification of large cetaceans, suggesting that the relationship between whale and vesicomyid evolution merits further scrutiny.

Acknowledgements. Many thanks go to the crews of the ATV, Turtle, Alvin, the Laney Chouest, and the Atlantis II. This work was supported by NOAA grant UAF-95-0040 to C.R.S., and NSF grants OCE-900162 to C.R.S., OCE9633131 to R.C.V., and NSF grant DEB9726573 to G.K.R. Additional support funds were provided to A.R.B. from the Conchologists of America. R. Feldman helped substantially with laboratory analyses and B. Glaser, P. Parnell, M. Stokes, and E. Vetter assisted with field collections. This is contribution no. 4789 from the School of Ocean and Earth Science and Technology, University of Hawaii at Manoa

\section{LITERATURE CITED}

Avise JC, Arnold J, Ball RM, Bermingham E, Lamb I, Neigel JE, Reeb CA, Saunders NC (1987) Intraspecific phylogeography: the mitochondrial DNA bridge between population genetics and systematics. Annu Rev Ecol Syst 18: $489-522$

Baco AR, Smith CR, Vrijenhoek RC (1996) Deep-sea whale skeleton communities on the California slope: structure, dynamics, and vent/seep affinities. EOS 76:0568

Barry JP, Kochevar RE, Baxter CH (1997) The influence of pore-water chemistry and physiology on the distribution of vesicomyid clams at cold seeps in Monterey Bay: implications for patterns of chemosynthetic community organization. Limnol Oceanogr 42:318-328

Bennett BA, Smith CR, Glaser B, Maybaum HL (1994) Faunal community structure of a chemoautotrophic assemblage on whale bones in the deep northeast Pacific Ocean. Mar Ecol Prog Ser 108:205-223

Berg CJ Jr (1985) Reproductive strategies of mollusks from abyssal hydrothermal vent communities. Biol Soc Wash Bull 6:185-197

Boss KJ, Turner RD (1980) The giant white clam from the Galapagos Rift, Calyptogena magnifica species novum. Malacologia 20:161-194

Briggs DEG, Crowther PR (1990) Paleobiology: a synthesis. Blackwell Scientific, Boston, MA.

Cary SC, Giovannoni SJ (1993) Transovarial inheritance of 
endosymbiotic bacteria in clams inhabiting deep-sea hydrothermal vents and cold seeps. Proc Natl Acad Sci 90: $5695-5699$

Cavanaugh CM (1983) Symbiotic chemoautotrophic bacteria in marine invertebrates from sulphide-rich habitats. Nature 302:58-61

Childress JJ, Felbeck H, Somero GN (1987) Symbiosis in the deep-sea. Sci Am 256:115-120

Deming JW, Reysenbach AL, Macko SA, Smith CR (1997) Evidence for the microbial basis of chemoautotrophic invertebrate community at a whale fall on the deep seafloor: Bone-colonizing bacteria and invertebrate endosymbionts. J Microsc Res Tech 37:162-170

Distel DL, Lane DJ, Olsen GJ, Giovannoni SJ, Pace B, Pace N, Stahl D, Felbeck H (1988) Sulfur-oxidizing bacterial endosymbionts: analysis of phylogeny and specificity by $16 \mathrm{~S}$ rRNA sequences. J Bacteriol 170:2506-2510

Doyle JJ, Dickinson E (1987) Preservation of plant samples for DNA restriction endonuclease analysis. Taxon 36:715-722

Endow K, Ohta S (1990) Occurrence of bacteria in the primary oocytes of vesicomyid clam Calyptogena soyoae. Mar Ecol Prog Ser 64:309-311

Felbeck H, Childress JJ, Somero GN (1983) Biochemical interactions between mollusks and their algal and bacterial symbionts. In: The Mollusca, Vol. 2, Environmental biochemistry and physiology. Academic Press, Orlando, p 331-358

Felsenstein J (1991) PHYLIP-phylogeny inference package (version 3.4). University of Washington, Seattle, WA

Fiala-Medioni A, LePennec M (1988) Structural adaptations in the gill of the Japanese subduction zone bivalves (Vesicomyidae) Calyptogena phaseoliformes and Calyptogena laubiere. Oceanol Acta 11:185-192

Fisher CR (1990) Chemoautotrophic and methanotrophic symbioses in marine invertebrates. Rev Aquat Sci 2:399-436

Folmer O, Black M, Hoeh W, Lutz R, Vrijenhoek R (1994) DNA primers for amplification of mitochondrial cytochrome c oxidase subunit I from diverse metazoan invertebrates. Mol Mar Biol Biotechnol 3(5):294-299

Fujioka K, Wada H, Okano H (1993) Torishima whale bone deep-sea animal community assemblage-new finding by Shinkai 6500 . J Geogr 102(5):507-517

Gaskin DE (1982) The ecology of whales and dolphins. Heinemann, Portsmouth, NH

Gibbs PE (1987) A new species of Phascolosoma (Sipuncula) associated with a decaying whale's skull trawled at $880 \mathrm{~m}$ depth in the South-west Pacific. NZ J Zool 14:135-137

Goedert JL, Squires RL, Barnes LG (1995) Paleoecology of whale-fall habitats from deep-water Oligocene rocks, Olympic Peninsula, Washington state. Paleogeogr, Paleoclim Paleoecol 1.18:151-1.58

Hoeh WR, Stewart DT, Sutherland BW, Zouros E (1996) Cytochrome $c$ oxidase sequence comparisons suggest an unusually high rate of mitochondrial DNA evolution in Mytilus (Mollusca: Bivalvia). Mol Biol Evol 13:418-421

Juan C, Oromi P, Hewitt GM (1996) Phylogeny of the genus Hegeter (Tenebrionidae, Coleoptera) and its colonization of the Canary Islands deduced from cytochrome oxidase I mitochondrial DNA sequences. Heredity 76:392-403

Kanie Y, Sakai I (1997) Chemosynthetic thraccid bivalve Nipponothracia, gen. Nov from the Lower Cretaceous and Middle Miocene mudstones in Japan. Venus Jpn J Malacol 56:205-220

Karl SA, Schutz S, Desbruyeres D, Lutz R, Vrijenhoek RC (1996) Molecular analysis of gene flow in the hydrothermal vent clam (Calyptogena magnifica). Mol Mar Biol Biotechnol 5:193-202
Kishino H. Hasegawa M (1989) Evaluation of the maximum likelihood estimate of the evolutionary tree topologies from DNA sequence data, and the branching order in Hominoidea. J Mol Evol 29:170-179

Kojima S, Segawa R, Kobayashi T, Hashimoto T, Fujikura K Hashimoto J, Ohta S (1995) Phylogenetic relationships among species of Calyptogena (Bivalvia: Vesicomyidae) collected around Japan revealed by nucleotide sequences of mitochondrial genes. Mar Biol 122:401-407

Kumar S. Tamura K, Nei M (1993) MEGA: molecular evolutionary genetic analysis, ver. 1.01. The Pennsylvania State University, University Park, PA

Maddison WP, Maddison DR (1992) MacClade. Sinauer Associates, Inc, Sunderland, MA

Marshall BA (1987) Osteopeltidae (Mollusca: Gastropoda): a new family of limpets associated with whale bone in the deep-sea. J Molluscan Stud 53:121-127

Marshall BA (1994) Deep-sea gastropods from the New Zealand region associated with recent whale bones and an Eocene turtle. Nautilus 108(1):1-8

McLean JH (1992) Cocculiniform limpets living on whale bone in the deep sea off California. J Molluscan Stud 58 : $401-414$

Naganuma T, Wada H, Fujioka K (1996) Biological community and sediment fatty acids associated with the deep-sea whale skeleton at the Torishima seamount. J Oceanogr 52 : $1-15$

Olsen GJ, Matsuda H, Hagstrom R, Overbeek R (1994) FastDNAml: a tool for construction of phylogenetic trees of DNA using maximum likelihood. CABIOS 10:41-48

Peek AS, Gustafson RG, Lutz RA, Vrijenhoek RC (1997) Evolutionary relationships of deep-sea hydrothermal vent and cold-water seep clams (Bivalvia: Vesicomyidae): results from the mitochondrial cytochrome oxidase subunit I. Mar Biol 130:151-161

Pettibone MH (1993) Polynoid polychaetes associated with a whale skeleton in the bathyal Santa Catalina Basin. Proc Biol Soc Wash 106(4):678-688

Saiki RK, Gelfland DH, Stoffel S, Scharf S, Higuchi R, Horn R, Mullis KB, Erlich HA (1988) Primer-directed enzymatic amplification of DNA with a thermostable DNA polymerase. Science 239:487-491

Scott KM, Fisher CR (1995) Physiological ecology of sulfide metabolism in hydrothermal vent and cold seep vesicomyid clams and vestimentiferan tube worms. Am Zool 35:102-11.1

Sibuet M, Olu K (1998) Biogeography, biodiversity, and fluid dependence of deep-sea cold-seep communities at active and passive margins. Deep-Sea Res 45:517-567

Smith CR (1992) Whale falls: chemosynthesis on the deep seafloor. Oceanus 35(3):74-78

Smith CR, Kukert $H_{1}$, Wheatcroft RA, Jumars PA, Deming JW (1989) Vent fauna on whale remains. Nature 341:27-28

Smith SW, Overbeek R, Woese CR, Gilbert W, Gillevet PM (1994) The genetic data environment and expandable GUI for multiple sequence analysis. CABIOS 10:671--675

Smith CR, Maybaum HL, Baco AR, Pope RH, Carpenter SD, Yager PL, Macko SA, Deming JW (1998) Sediment community structure around a whale skeleton in the deep northeast Pacific: macrofaunal, microbial and bioturbation effects. Deep-Sea Res 45:335-364

Swofford DL (1993) PAUP: phylogenetic analysis using parsimony, version 3.1.1. Illinois Natural History Survey, Champaign, IL

Tunnicliffe V (1991) The biology of hydrothermal vents: ecology and evolution. Oceanogr Mar Biol Annu Rev 29: $319-407$ 
Vetter RD (1985) Elemental sulfur in the gills of three species of clams containing chemoautotrophic symbiotic bacteria a possible energy storage compound. Mar Biol 88:33-42

Vrijenhoek RC, Schutz SJ, Gustafson RG, Lutz RA (1994) Cryptic species of deep-sea clams (Mollusca: Bivalvia. Vesicomyidae) from hydrothermal vents and cold-water seep environments. Deep-Sea Res I 41(8):1171-1189

Editorial responsibility: Otto Kinne (Editor),

Oldendorf/Luhe, Germany
Wada H, Naganuma T, Fujioka K, Kitazato H, Kawamura K Akazawa Y (1994) The discovery of the Torishima whale bone animal community and its meaning -the results of the revisit dives by the Shinkai 6500 . JAMSTEC J Deep Sea Res 10:28-47

Warén A (1989) New and little known mollusca from Iceland. Sarsia $74: 1-28$

Submitted: July 16, 1998; Accepted: January 25, 1999 Proofs received from author(s): May 25, 1999 